\title{
家庭與社會公義
}

\section{Family and Social Justice}

\author{
翁若愚
}

\section{Lawrence Yung}

\section{Abstract}

Mark Cherry's article identifies claims regarding individual autonomy, gender neutrality, and rights to sexual freedom as taking a commanding place within the secular liberal recasting of the family to grant same-sex marriage the same legal status as heterosexual marriage. Cherry refers to Plato's proposal of abolishing family in Republic (Book V) as a precursor to reforming the family to engineer currently favored versions of social justice. This paper adds to the discussion on family and social justice with an explication of this proposal of abolishing family and a comparison with the Confucian ideal of Great Unity.

馬克查瑞的文章探討了西方社會內傳統觀念與自由主義對婚 姻及家庭生活截然不同的觀點及其此消彼長所衍生的社會影響和 文化轉變。查瑞明確提出如果我們希望保持儒家的文化傳統, 就 不應該重蹈西方社會的覆轍。查瑞引用許多跨文化研究的數據指 出, 在完整家庭成長的人在社會、情緒、心理、財政上較佔優勢。 不完整或非傳統的家庭對子女的身心均有深遠的影響。例如單親 家庭長大的人更容易陷入貧困、罪案、輟學以至未成年懷孕。因

\footnotetext{
翁若愚, 香港城市大學公共政策學系高級導師, 中國香港。

Lawrence Yung, Instructor, Department of Public Policy, City University of Hong Kong, Hong Kong.

《中外醫學哲學》XVI:2 (2018 年) : 頁 45-48。

International Journal of Chinese \& Comparative Philosophy of Medicine XVI:2 (2018), pp. 45-48.

(C) Copyright 2018 by Global Scholarly Publications.
} 
為傳統的家庭是一種標準的社會存在對人們的生活具有重要的道 德規範作用。

西方社會世俗的自由派對婚姻及家庭有另一套南轅北較的看 法。他們重視個人自主、性別中立及性自由的權利。這些流行於 當前西方社會的道德原則構成自由主義所信仰的社會公義。他們 視傳統的家庭為通向平等公義及性別中立的主要障礙。因此他們 希望改革家庭, 信仰自由平等, 故致力將婚姻重新塑造成為自主 的個體之間的一種平等的社會契約關係。

傳統的家庭內各成員有特定的角色及責任, 成員間亦互相負 有責任, 不會把成員視為分割的個體。對外則着重維護傳承家族 利益, 凡事必以家庭成員的福祉作優先考慮。本來首先顧及家庭 成員的利益是家庭應有之義, 可是這樣的做法, 必然影響了社會 上的平等機會。對於追求平等機會的自由派而言社會上許多的不 公義, 正是源於家庭的徇私。在自由主義的道德願景下, 平等的 社會才能彰顯社會公義。傳統的家庭對外則厚此薄彼, 着重維護 家族成員利益, 不惜犧牲社會上非家庭成員的平等機會。對內則 有家庭角色及權力之分, 如父母與子女之分, 夫妻之分, 長幼之 分。傳統的家庭不符合自由主義所重視的平等、自主原則, 無助 於推動自由主義所理解的社會公義。自由主義追求平等, 致力於 消除就業市場的性別歧視、年齡歧視、殘疾歧視等等。家庭的私 人領域與這些議題多少也有點關係。其他的議題如婦女的角色與 地位、同性婚姻合法化就更加聚焦於家庭之上。

查瑞認為近代西方文化鼓吹性自由的權利, 因此婚外性行為 及同居不婚都得到默許。這些現象對西方社會有重大影響, 演變 至出現立法行動及法庭裁判重新定義婚姻, 賦予同性婚姻法律地 位。2015 年美國聯邦最高法院在〈奥貝格費爾訴霍奇斯案〉裁決 同性婚姻的權利受憲法保障, 各州不得立法禁止。推動同性戀平 權, 改變傳統婚姻及家庭生活固有方式所衍生的不公義是自由派 的核心目標。在同性婚姻合法化的議題上, 自由派成功爭取了同 
性婚姻的法律保障, 達到改變社會的核心目標。可是社會因此分 化不和諧。同性婚姻受到法律保障, 社會上對婚姻持有傳統觀念 的人受到邊緣化。現任美國最高法院大法官安東尼阿利托清晰地 表達了此關注。

查瑞指出以改革家庭入手，推動社會進步、達致公義社會的 濫觞可上溯到希臘時期的柏拉圖。以下筆者希望作一些延伸的補 充説明。首先在柏拉圖《理想國》的討論中, 蘇格拉底提出廢除 家庭的主張只適用於監護者(guardian)的階層, 並不適用於其他的 兩個階層：輔助者 (auxiliary)及生產者(producer)。這一點往往被 忽略。人數上, 監護者只佔城邦人口的小數（有學者推斷最多不 過五千之數）。其他的兩個階層佔絕大多數。蘇格拉底認為政治 權力結合私人財產必會導致當權者結黨營私, 影響管治。所以監 護者必須過着公社式的生活, 沒有私人財產, 連丈夫、妻子、子 女也是共有的。其他的兩個階層可以擁有私人財產, 可以結婚, 組織家庭生兒育女。

面對社會與家庭二元對立的難題，在理想國的討論中，蘇格 拉底提出的解決辦法並不是以取締家庭的方式消滅親屬關係的紐 帶, 而是透過在監護者的階層推行全面公社化的方式, 把親屬關 係推向極致：所有的監護者組成一個不以血緣为基礎的大家庭共 同體。監護者沒有私產也不能如常人一般結婚組織家庭。在特定 的節日, 小數的適齡監護者（男的在二十五到五十五歲，女的在 二十到四十歲）會被選出結合。新生的嬰兒與親生父母分離, 不 分男女接受公社同樣的捵養教育。在這樣的公社制度下年幼的監 護者視所有年長的監護者為自己的父母。年長的監護者也視所有 年幼的監護者為自己的子女。蘇格拉底認為只有這樣的一個不以 血緣作基礎的大家庭共同體, 各成員才能不分彼此地團結一致奉 公行義。

在《理想國》的討論中，蘇格拉底提出的公義社會有別於當 代西方自由主義提倡的公義社會。自由主義的公義社會必須突顯 
平等自由、個人自主、性別中立及性自由權利的道德原則。蘇格 拉底提出的公義社會則建基於和諧、效率及美德之上。對蘇格拉 底而言, 快樂並不是來自行使權利或選擇自己喜歡做的事, 而是 只有通過實踐美德才能得到快樂。儒家思想也重視德性的培養, 所以有修身齊家治國平天下的主張。君子由正其心開始, 走出修 身齊家治國平天下的路。不同的是, 蘇格拉底理想城邦的監護者 過着公社式的生活。儒家的君子則過着傳統的家庭生活。另外儒 家的理想大同社會, 天下為公, 「人不獨親其親, 不獨子其子」, 這些與蘇格拉底的理想國相似, 但儒家沒有主張在任何階層廢除 傳統的家庭。

\section{參考文獻 References}

馬克·查瑞：〈婚姻與家庭生活僅僅是相互同意的個人之間的契約嗎? 不同的道德基礎及社會轉化〉, 《中外醫學哲學》, 2018 年, 第 XVI 卷, 第 2 期, 頁 7-28 。 Cherry, J. Mark. “Are Marriage and Family Life Merely Contractual Agreements Among Consenting Parties? Shifting Moral Foundations and Social Transformation," International Journal of Chinese \& Comparative Philosophy of Medicine XVI:2 (2018), pp.7-28.

Grube, G. “The Marriage Laws in Plato’s Republic,” The Classical Quarterly 21:2 (1927), pp. 95-99.

Grube, G., \& Reeve, C. "Republic,” Indianapolis: Hackett Pub, 1992.

Okin, Susan Moller. "Philosopher Queens and Private Wives: Plato on Women and the Family," Philosophy and Public Affairs 6:4 (1977), pp. 345-369. 